\title{
Closed head injury in rats. Histopathological aspects in an experimental weight drop model $^{1}$
}

\author{
Trauma craniano fechado em ratos. Aspectos histopatológicos em um modelo experimental de \\ queda de peso
}

\author{
Danilo dos Santos Silva', José Nazareno Pearce de Oliveira Brito"I, Jerúsia Oliveira Ibiapina ${ }^{\mathrm{III}}$, Marcel Fernando Miranda \\ Batista Lima ${ }^{I}$, Andréa Ribeiro Gonçalves de Vasconcelos Medeiros' ${ }^{\mathrm{I}}$, Bárbara Hamedy Carvalho e Queiroz ${ }^{\mathrm{I}}$, Aline Lariessy \\ Campos Paiva ${ }^{I}$, Vanessa Olímpio de Melo Guedes ${ }^{I}$
}

${ }^{\mathrm{I}}$ Graduate student, Faculty of Medicine, UESPI, Piaui, Brazil.

Danilo dos Santos Silva: Conception, design, intellectual and scientific content of the study; acquisition and interpretation of data; manuscript writing. Marcel Fernando Miranda Batista Lima: Collection and processing of the study informations, manuscript writing.

Andréa Ribeiro Gonçalves de Vasconcelos Medeiros: Acquisition of data, histometric examination, manuscript writing.

Bárbara Hamedy Carvalho e Queiroz: Acquisition of data, helped with technical procedures.

Aline Lariessy Campos Paiva: Manuscript writing and translation.

Vanessa Olímpio de Melo Guedes: Technical procedures and histopathological examinations.

IIPhD, Full Professor, Department of Neurology and Neurosurgery, Faculty of Medicine, UESPI, Piaui, Brazil. Tutor, analysis and interpretation of data, manuscript writing, critical revision.

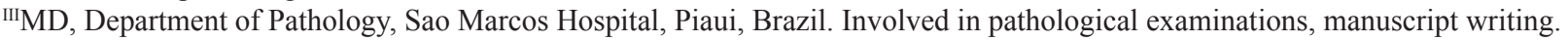

\section{ABSTRACT}

PURPOSE: To study histopathological findings due to a model of closed head injury by weight loss in rats.

METHODS: A platform was used to induce closed cranial lesion controlled by weight loss with a known and predefined energy. 25 male Wistar rats (Rattus novergicus albinus) were divided in five equal groups which received different cranial impact energy levels: G1, G2, G3 and G4 with 0.234J, 0.5J, 0.762J and 1J respectively and G5 (Sham). Under the effect of analgesia, the brain of each group was collected and prepared for histopathological analysis by conventional optic microscopy.

RESULTS: It was observed greater number of injured neurons in animals of group 4, however neuronal death also could be noticed in animals of group 5. Intraparenchymal hemorrhages were more frequent in animals of group 4 and the cytotoxic brain swelling and vascular congestion were more intense in this group.

CONCLUSION: The histopathological analysis of these findings allowed to observe typical cranial trauma alterations and these keep close relation with impact energy.

Key words: Models, Animal. Brain Injuries. Pathology. Rats.

RESUMO

OBJETIVO: Investigar as alterações histopatológicas produzidas por um modelo de trauma craniano fechado por queda de peso em ratos.

MÉTODOS: Utilizando uma plataforma para produção de lesão craniana fechada controlada por queda de peso com energia prédefinida e conhecida, 25 ratos Wistar machos (Rattus norvegicus albinus) foram divididos em cinco grupos iguais que receberam níveis diferentes de energia de impacto craniano: G1, G2, G3 e G4 com 0,234J, 0,5J, 0,762J e 1J respectivamente e G5 (Sham). Sob analgesia, cada grupo teve seus encéfalos coletados e processados para análise histopatológica por microscopia óptica convencional.

RESULTADOS: Houve maior número de neurônios lesados em animais do grupo 4, mas morte neuronal também pôde ser constatada nos animais do grupo 5. Hemorragias parenquimatosas foram mais frequentes nos animais do grupo 4 e o inchaço cerebral citotóxico e congestão vascular foram mais intensos neste grupo.

CONCLUSÃO: Os achados à análise histopatológica permitem observar alterações típicas do trauma craniano e estas guardaram proporção direta com a energia do impacto.

Descritores: Modelos Animais. Traumatismos Encefálicos. Patologia. Ratos. 


\section{Introduction}

Experimental cranial trauma models try to reproduce the physiopathology, macro and microscopic alterations in traumatic brain lesions in humans so as to study new therapeutic approaches ${ }^{1-3}$.

Weight loss models to produce closed head traumas have been used to create diffuse lesions through the energy transfer between the weight in freefall and the experimental animal head. Marmarou et al. ${ }^{4} \mathrm{~A}$ have described histopathological alterations observed on a weight loss model in that $450 \mathrm{mg}$ falls under a metallic disk fixed to the intact animal head which was supported by a foam bed ${ }^{4}$. At the histopathological findings, it could be observed petechial hemorrhages in the brain stem. Microscopically, the model has produced generalized lesions in neurons, axons and microvasculature. Neuronal lesion was observed bilaterally in the brain cortex. Cerebral edema, mainly presenting as astrocytic pericilar swelling, was also been observed in these cortex areas and in the brain stem ${ }^{5}$.

In this study, the model uses simple physical principles to produce a closed head injury and was prepared by using descriptions of other similar instruments reported in literature ${ }^{3,4,6}$ that were already used in head trauma experimental surgery researches at the experimental surgery laboratory from Piaui State University (UESPI). Silva et al. ${ }^{7}$, as well as the study developed by Dixon et al. ${ }^{8}$ with controlled cortical impact in rats, investigated systematically the effects of different levels of energy in closed head trauma in rats considering neurological, cardiovascular and histopathologycal variants, and this article have detailed the last parameter. Furthermore, Silva et al. ${ }^{7}$ report low costs, appropriate representation of clinical and macroscopical findings of the closed head trauma to experimental surgery researches and emphasize the easiness of physical principles reproduction of this kind of cerebral lesion model.

On the basis that impact apparatus characteristics and their components and considering experimental animal particularities, these models could present different findings on optic microscopy. This study aims to evaluate microscopic alterations produced by different energy levels using this closed head impact platform by weight loss.

\section{Methods}

This Research was approved by an Animal Experimentation Ethics Committee and its project is according to the animal ethics principles for experimentation (Health, Human and Technology Sciences School of Piaui Ethics Committee protocol $\left.\mathrm{n}^{\circ} 0001 / 10\right)$.

Twenty-five adult Wistar rats (Rattus norvegicus albinus), originally from the Animal Colony of the Piaui State University (UESPI), were clinically examined, selected and packed in standard cages, under $25^{\circ} \mathrm{C}$ ambient temperature and 12 hours cycle of light per day. These animals weighed between $230 \mathrm{~g}$ and $300 \mathrm{~g}$ and had about 100 to 120 days of age, all male. They were divided in equal groups of five animals.

\section{Experimental delineation}

All animals of this research were submitted to the same anesthetic protocol assisted by a veterinary. It consisted in the management of pre-anesthetic drugs (xylazine $2 \%, 5 \mathrm{mg} / \mathrm{kg}$ by subcuteneaously and fentanyl $0.032 \mathrm{mg} / \mathrm{kg}$ intraperitoneally) and propofol $(64.63 \mathrm{mg} / \mathrm{kg}$ intraperitoneally). When the proper anesthetic level was observed, each animal was submitted to a specific trauma protocol for it group, with different quantity of energy, that were: Group 1 $=0.234 \mathrm{~J}$; Group 2 $=0.5 \mathrm{~J}$, Group 3=0.762J e Group 4=1J of energy, being the group 5 a Sham in which the animals underwent the same anesthetic protocol, but not to the trauma

The head trauma was developed by a controlled drop of metallic spheres with different weights released through a duct always from the same height in a platform that was designed in order to maintain the experimental animal head partially fixed above rigidity bulkhead in accordance with was described by Silva et al. ${ }^{7}$. This platform was set up according to descriptions of it in the literature ${ }^{1,4-6,9}$ and under adaptations. It was already used in head trauma experimental surgery and trauma surgeries researches at Piaui State University, Faculty of Medicine. After being launched by freefall, the sphere transfers its energy to the animal head which was positioned in the platform reaching its median portion, in the center of the skullcap without group variations. The sphere friction against the equipment wall was worthless and its path was rectilinear and taproot to the animal head surface, reaching it only once.

New dosages of fentanyl were injected as soon as the drug analgesic effect decreases (mean of 40 minutes) until 80 minutes after the trauma were completed.

\section{Anatomopathological study}

Each animal was killed by deepening the anesthesia by using Phenobarbital and had their encephala removed. In the cases that the animal did not survive to impact, immediately its encephalon was removed. Encephala were carefully collected in 
block after extensive craniectomy developed by using an electric drill. Anatomical specimen were packed in buffered $10 \%$ formalin solution, which $\mathrm{pH}$ was 7.4. After being fixed, the encephalic samples were processed in histotechnical with paraffin permeation and microtomy with incisions of thickness measuring $5 \mu \mathrm{m}$ and stained by hematoxynin-eosin allowing histopathological examination. The microscopic analysis was performed by a pathologist physician with the assistance of a Nixon model Eclipse E200 conventional optic microscopic adapted with digital photomicrography, by analyzing these parameters: number of lesion neurons by high power field (400 times), number of intraparenchymal hemorrhages foci and a subjective study in which qualitative variables, such as cerebral swelling magnitude, vascular congestion and petechiae hemorrhage were evaluated.

\section{Statistical analyses}

To evaluate the relation between continuous quantitative variables (mean of necrotic neurons by high power field and energy level involved in the trauma) it was used the Pearson correlation coefficient.

\section{Results}

The histopathological evaluation was based in objectives and subjective variables. The former refers to the mean of lesion neurons by high power field and number of intraparechymal hemorrhages foci. Despite animals form Sham group did not undergone to cranial trauma, they also presented raised number of lesion neurons, nevertheless the necrotic neurons mean was greater in those groups which were undergone to the impact. It was found positive correlation between the variables: impact energy and necrotic neurons mean by high Power Field. This correlation was also strong and has a correlation coefficient (r) of 0.863 and determination coefficient $\left(\mathrm{r}^{2}\right)$ was 0.746 showing that approximately $75 \%$ of the range in the mean of necrotic neurons by microscopic high Power Field is explained by the impact energy range (Figure 1). The number of intraparenchymal hemorrhage foci also increased in accordance with the trauma energy level raise ( two foci observed in the greater impact energy group against one further test groups and none hemorrhagic focus in Sham).

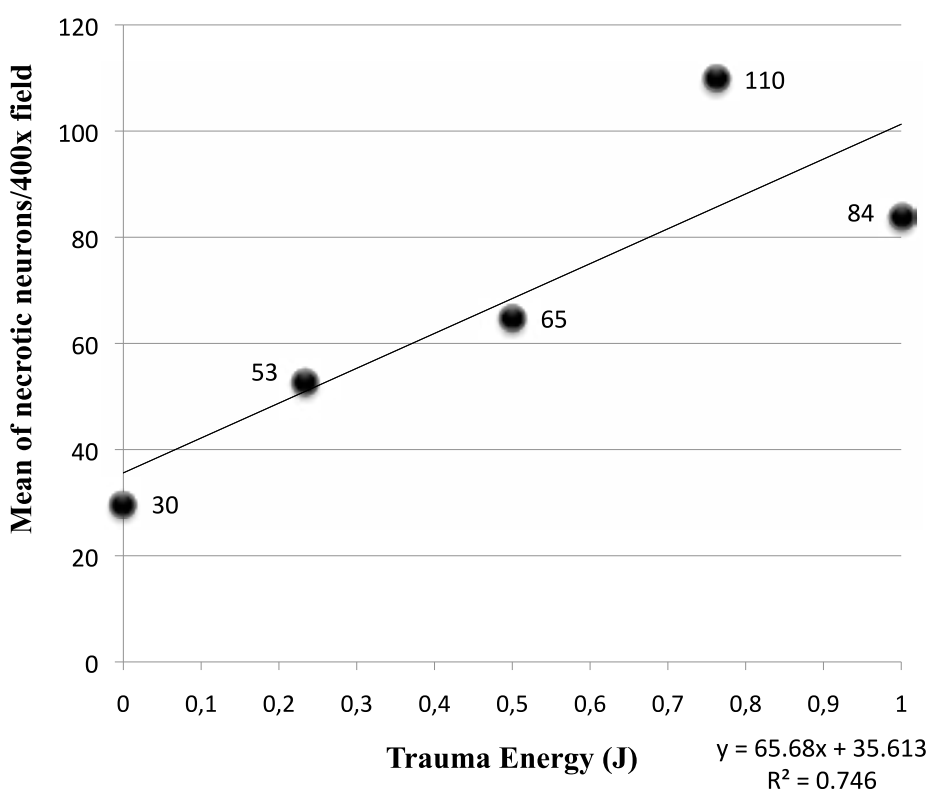

FIGURE 1 - This figure demonstrates strong positive correlation ( $\mathrm{r}=0.86)$ between the trauma energy and the mean of necrotic neurons by high power Field in microscopic analysis.

The subjective variables were measured through comparison of the tissues obtained with the control group. As illustrated in Table 1, the subjective variables observation revealed an increase according to the energy level rising related with the trauma. The mainly microscopic histopathological findings are illustrated on Figures $2 \mathrm{~A}$ and $2 \mathrm{~B}$.

TABLE 1 - Analysis of subjective microscopic variables in traumatic brain injury with increased levels of impact energy for closed head trauma.

\begin{tabular}{|c|c|c|c|c|c|}
\hline \multirow[t]{2}{*}{ Microscopic variables } & \multicolumn{5}{|c|}{ Groups } \\
\hline & 1 & 2 & 3 & 4 & 5 \\
\hline Brain swelling & 0 & + & ++ & +++ & 0 \\
\hline Vascular congestion & + & + & ++ & +++ & + \\
\hline Petechiae & + & + & + & ++ & 0 \\
\hline
\end{tabular}



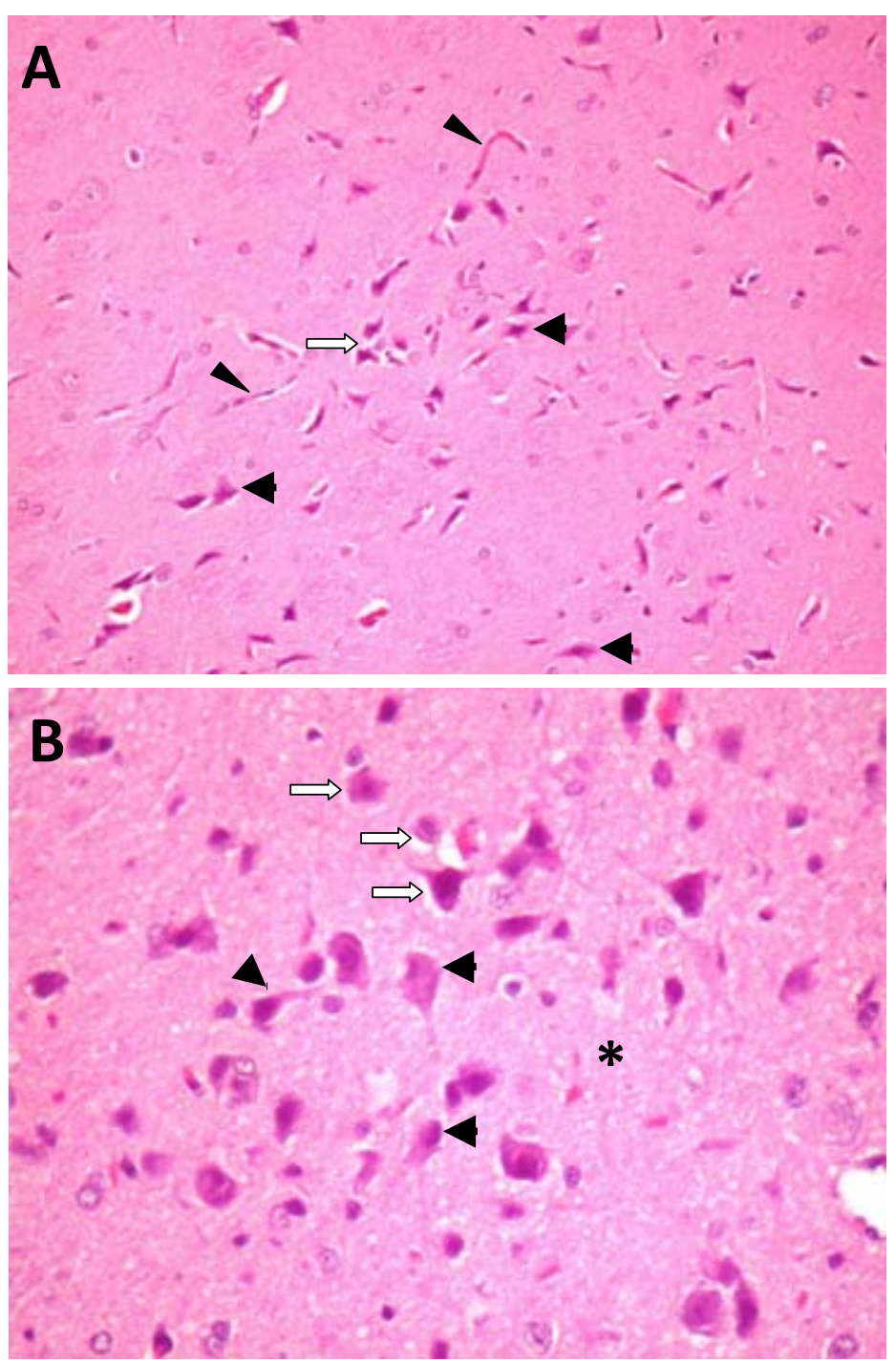

FIGURE 2 - Fotomicroscopic of cerebral hemispheric region demonstrating greater number of ischemic neurons. A: ischemic neurons (Black arrows - citoplasmatic eosinophilia, nuclear pyknosis and non evident nucleoli), perineural vacuolization (White Arrow) and vascular congestion (arrowheads). Hematoxylin-eosin 200x. B: ischemic neurons (black arrows) perineural vacuolization (white arrows) and brain edema (asterisk). Hematoxylin-eosin 400x.

\section{Discussion}

Many experimental models were performed in the last decades so as to reproduce head trauma in laboratory ${ }^{1-3}$. A group of these studies uses the weight drop right trauma model mechanism or produces encephalic lesions through using pneumatic pistons regulated by compressed air ${ }^{10}$. The head trauma experimental models intend to reproduce the complex physiopathology of traumatic brain injury in laboratory in order to allow the development of new therapeutic approaches ${ }^{1,2}$.

In this study and in other similar, which use closed head impact by weight drop to create cerebral lesions, there is special limitation for reproduce macroscopic supratentorial focal lesions even in higher trauma energy levels, although a great diversity of microscopic lesions could be described by using this kind of model.

Foda and Marmarou $^{5}$ have described a range of histopathologycal alterations related with impact provoked by a body of unknown mass freefall under rats static head. The authors emphasize the close proportionality between neuronal lesions intensity observed and the trauma magnitude. The animals had neuronal lesions localized preferential in supraventricular regions of brain cortex and immediately below the point of impact. These findings are correlated with emergence of edema and vascular congestion in the same region. These authors could observe mainly diffuse lesions with compatible findings with encephalic lesions observed in humans after head trauma, such as the findings obtained by Lighthall ${ }^{11}$ in his mechanical cerebrum lesion experimental model in Mustela putoris furo.

The weight drop closed head trauma model presents many particularities in this study. Metallic helmets fixed under the animal head were not used as in other similar researches ${ }^{4}$. This leads to the direct energy transmission from the sphere to the animal head. In this study the number of lesion neurons by high power field was soaring as the sphere weight rise and consequently to impact energy (Table 1). Nevertheless it is also possible observe a great number of ischemic neurons in animals from group 5 (Table 1). It is possible that the effect of anesthetic and analgesic agents used in this anesthetic protocol were capable of producing respiratory and cardiac depression enough to reduce cerebral blood flow causing some neuronal injury level. Contradictorily the mean of injured neurons at the animal encephala from group 4 was lower than that observed in animals from group 3 regardless the greater sphere weight involved in that group trauma. The authors attribute this finding to the little break between the trauma and group 4 animal deaths (about 10 minutes after trauma). This period would not be enough for complex traumatic cerebral injury physiopathology completing as occur in animals from group 3 that remained alive during 80 minutes after the impact. In this interval some neuronal metabolism and cerebral blood flow alterations were processed and also cardiac and respiratory systemic modifications related to head trauma and a greater number of neurons died in the presence of a superior exposure time to these alterations.

The histopathologycal findings described in this study are close of those observed in others researches involving closed head trauma in rats produced by others types of devices such as those operated by pneumatic pressure ${ }^{10}$. 


\section{Conclusion}

The closed head trauma produced by weight drop used in this review has allowed the reproduction of the mainly histopathological alterations observed in the complex physiopathology of traumatic brain injury and are compatible with proposes of studies in experimental head trauma surgery in rats.

\section{References}

1. Cernak I. Animal models of head trauma. NeuroRx. 2005;2(3):41022.

2. Park HK, Fernandez I, Dujovny M, Diaz FG. Experimental animal models of traumatic brain injury: medical and biomechanical mechanism. Crit Rev Neurosurg. 1999;9:44-52.

3. Engelborghs K, Verlooy J, van Reempts J, van Deuren B, van de Ven M, Borgers M. Temporal changes in intracranial pressure in a modified experimental model of closed head injury. J Neurosurg. 1998;89:796-806.

4. Marmarou A, Foda MA, van den Brink W, Campbell J, Kita H, Demetriadou K. A new model of diffuse brain injury in rats. Part I: Pathophysiology and biomechanics. J Neurosurg. 1994;80(2):291300.

5. Foda MA, Marmarou A. A new model of diffuse brain injury in rats. Part II: Morphological characterization. J Neurosurg. 1994;80(2):301-13.

6. Adelson PD, Robichaud P, Hamilton RL, Kochanek PM. A model of traumatic brain injury in the immature rat. J Neurosurg. 1996;85:877-84.

7. Silva DS, Brito JNPO, Ibiapina JO, Lima MFMB, Medeiros ARGV, Queiroz BHC, Guedes VOM. Traumatic brain injury: clinical and pathological parameters in an experimental weightdrop model. Acta Cir. Bras. 2011;26(2):94-100. Available from: http://www.scielo.br/scielo.php?script=sci_arttext\&pid=S0102$86502011000200004 \& \operatorname{lng}=\mathrm{pt}$.

8. Dixon CE, Clifton GL, Lighthall JW, Yaghmai AA, Hayes RL. A controlled cortical impact model of traumatic brain injury in the rat. J Neurosci Methods. 1991;39:253-62.

9. Onyszchuk G, Al-Hafeza B, He Y, Bilgen M, Berman NEJ, Brooks WM. A Mouse model of sensorimotor controlled cortical impact: characterization using longitudinal magnetic resonance imaging, behavioral assessments and histology. J Neurosci Methods. 2007;160(2):187-96.

10. Dvilevicius AE, Prandini MN, Dobrowolski S, Barbosa AC. Estudo de traumatismo cranioencefálico experimental em ratos com aparelho de impacto cortical controlado. Arq Bras Neurocir. 2008;27(2):42-6.

11. Lighthall JW. Controlled cortical impact: a new experimental brain injury model. J Neurotrauma. 1988;5:1-15.

\section{Acknowledgement}

We would like to thank the special contribution of Professor Master Airton Mendes Conde Junior from Federal University of Piaui (UFPI).

\section{Correspondence:}

Prof. Dr. José Nazareno Pearce de Oliveira Brito

Rua Desembargador César do Rego Monteiro, 1220

64049-580 Teresina - PI Brasil

Tel.: (55 86)3232-0658

nazapearce@uol.com.br

Received: November 17, 2011

Review: January 18, 2012

Accepted: February 15, 2012

Conflict of interest: none

Financial source: National Council for Scientific and Technological Development (CNPq)

${ }^{1}$ Research performed at Department of Experimental Surgery, Faculty of Medicine, Piaui State University (UESPI) and Department of Pathology of Sao Marcos Hospital, Piaui Association for Cancer Care, Teresina-PI 